\title{
Die skeppingsmites as simbole van psigiese prosesse
}

\author{
JP Naudé
}

\section{Abstract \\ Creation myths as symbols of psychic processes}

The thesis which has been taken from the Jungian psychology and which is discussed in this article, is the following: Creation myths represent unconscious and preconscious psychic processes which constitute the origin of the development of the human being's consciousness of the world. This implies that the creation myths don't describe the origin of the cosmos. They refer to psychic processes which accompany the growth of human consciousness out of the unconscious. This growth process is discussed in terms of the Jungian concepts of the collective unconscious, archetypes, consciousness and ego, the personal unconscious and complexes, the persona and the shadow, the self and the individuation process.

\section{INLEIDING}

Skeppingsmites vorm 'n eiesoortige en belangrike groepvertelling binne die totaliteit van oorgelewerde verhale en mites van antieke volke in die wêreld.

Skeppingsmites was gewoonlik op 'n plegtige en waardige wyse vertel. 'They convey a mood which implies that what is said will concern the basic things of existence, something more than is contained in other myths' (Von Franz 1972: 5). Die vertel van skeppingsmites het dikwels saamgeval met ipisiasierites en het veral aandag geskenk aan die vraag na die betekenis van die menslike eksistensie èn na die betekenis van die bestaan van die totale kosmos.

\section{DIE PSIGOLOGIESE SITZ IM LEBEN VAN DIE SKEPPINGSMITES}

Die mens kan van geen ander realiteit praat as die vorm van realiteit wat deel is van die bewuste inhoud van die psige nie. Al realiteit waarvan ons dus kan praat, is die realiteit waarvan ons bewus is.

- Studiestuk oor Persoonlikheidsielkunde as deel van die BA (Hons)-kursus, ingedien by die Departement Sielkunde, Universiteit van Pretoria. 
Waarneming van die realiteit is egter altyd subjektief gekleur. Dit beteken dat die enigste realiteit waaroor ons kan praat of waarby ons werklik belang het, is die beeld van die realiteit in ons bewussynsveld.

Waar die mens egter die grense van die subjektiewe waargenome werklikheid oorskry, tree die onbewuste in werking. Die onbewuste produseer modelle wat verband hou met die misterie van die menslike natuur en eksistensie en die ontstaan van die skepping. Hierdie modelle van die onbewuste word deur Carl Jung in sy psigo-analitiese model met die begrip argetipes beskryf (Engler 1985: 87).

Waar die mens met die onbekende te doen kry, waar die bekende realiteit eindig, projekteer hy ' $n$ argetipiese beeld. 'Die geheimenis van die oorsprong van die natuur en die mens gee dus aanleiding tot ' $n$ verskeidenheid voorstellings daarvan, wat terselfdertyd argetipes van die onbewuste weerspieël' (Grobler 1978: 81).

Dieselfde proses vind plaas wanneer die menslike verstand teen die grense van die onbekende stuit. Wanneer daar byvoorbeeld na antieke kaarte gekyk word, soos byvoorbeeld dié van Griekeland, word Griekeland min of meer in die middel van die kaart duidelik aangetoon. Op die grenslyne word die minder bekende aangrensende gebiede verwronge en vaag aangedui. Die gebiede wat onbekend is, word eenvoudig aangedui met 'n tekening van die Uroboros, die slang wat sy eie stert eet. Dié antieke kaart word verder versier met tekeninge van diere, monsters en demoniese figure. Vier koppe met monde wat die wind uit die vier windrigtings blaas, word in die hoeke van die kaart geteken.

Die Uroboros, diere, monsters en demone is argetipes wat in die onbewuste van die mens teenwoordig is. Sodra die mens se bewussyn die grense van die empiriese wêreld ooskry na die onbekende toe, tree die onbewuste in werking en projekteer dit argetipiese beelde.

Met betrekking tot die psigologiese betekenis van die teenwoordigheid van argetipiese simbole by die antieke kaarte, merk Marie-Louise von Franz die volgende op: 'These maps demonstrate ad oculos that wherever known reality stops, where we touch the unknown, there we project an archetypal image' (Von Franz 1972: 5).

Skeppingsmites is pogings van die mens om die onbekende binne te dring. Dit is voorstellings van onbewuste en voorbewuste prosesse wat die ontstaan van die mens se bewuswording van die wêreld en homself beskryf. Daarom kan die psigologiese Sitz im Leben van die skeppingsmites as die prosesse van die onbewuste van die menslike psige beskryf word. 


\section{PSIGIESE PROSESSE VOLGENS CG JUNG}

\subsection{Inleiding}

Noudat die Sitz im Leben van die skeppingsmites as die prosesse van die onbewuste van die menslike psige beskryf is, is dit nodig om kortliks die hoofmomente van Jung se beskouings oor die psige weer te gee. Die doel hiervan is om vanuit hierdie beeld die prosesse van die onbewuste en voorbewuste te beskryf en hulle verband met die vorming van skeppingsmites aan te toon.

\subsection{Dieptesielkunde}

Die psigo-analitiese of dieptesielkunde is 'n skool wat die ervaring en gedrag van die mens in terme van die fenomene van die onbewuste, en veral die diep onbewuste, verklaar. Daar is 'n groot aantal psigo-analitiese teorieë, maar hulle word hoofsaaklik gekenmerk deur die insluiting van die onbewuste as deel van die struktuur van die persoonlikheid.

Brammer \& Shostrom (1982: 41) beskryf hierdie psigologiese rigting soos volg:

The psychoanalytic approach stresses the importance of the clients life history (psychosexual development), the influence of genetic impulses (instincts), a life energy (libido), the influence of early experiences on later personality of the individual, and the irrationality and unconscious sources of much of human behavior.

Jung se teorie is binne hierdie raamwerk 'ingestel op die diepste laag van die onbewuste en leen hom goed tot verklaring van kulturele psigiese verskynsels en produkte' (Grobler 1978: ii).

\subsection{Die kollektiewe onbewuste}

Jung het in sy studie van 'n veelheid van mense van baie kulture gevind dat daar op universele grondslag 'n herhaling van dieselfde simbole en mitologiese temas voorkom in delusies en drome van moderne mense in verskillende lande, in argeologiese opgrawings, godsdienstige rituele en alchemistiese voorskrifte:

These contents have one outstanding peculiarity, and that is their 
mythological character. It is as if they belong to a pattern not peculiar to any particular mind or person, but rather to a pattern peculiar to mankind in general (Jung 1977: 37).

Jung het die begrip kollektiewe onbewuste geskep om hierdie inhoude se ontstaan te verklaar. Die kollektiewe onbewuste is die oorspronklike, primitiewe psige waaruit die bewuste as deel van die evolusieproses van die mens ontwikkel het. Net soos instinkte, is dit oorgeërf, dus biologies vasgelê in almal wat aan dieselfde spesie behoort. Dit behels ook die toerusting waarmee die baba gebore word en waaruit sy bewussyn ontwikkel. Dit is ' $n$ bron van psigiese energie, skeppende vermoë en wysheid vir die mens.

Die kollektiewe onbewuste is transpersoonlik. 'That is to say, it extends across persons. It consists of certain potentialities that we all share because we are all human beings' (Engler 1985: 86). Dit word dus kollektief genoem omdat dit universeel by alle mense voorkom. Dit word ook objektief genoem omdat dit nie op persoonlike ervarings berus nie, maar oorgeërf word. Dit word gekenmerk deur mitologiese, bonatuurlike en numineuse eienskappe, terwyl die bestaan daarvan deur drome, mitologie en transkulturele data gedemonstreer kan word.

\subsection{Die argetipes}

Die argetipes is die inhoude van die kollektiewe onbewuste van die menslike psige. Barbara Engler definieer ' $n$ argetipe soos volg: 'An archetype is a universal thought form or disposition to perceive the world in certain ways' (Engler 1985: 87).

Elise Grobler (1978: 25) gee 'n meer uitgebreide definisie:

'n Argetipe kan beskryf word as 'n disposisie wat op 'n gegewe moment in die ontwikkeling van die menslike gees begin funksioneer en die materiaal van die bewussyn in patrone rangskik. Dit is 'n potensiaal om die wêreld te ervaar, te interpreteer en daarop te reageer.

Die argetipes kan nooit ten volle geken en beskryf word nie. Hulle verskyn aan die mens in 'n gepersonifieerde of gesimboliseerde vorm en kan die bewuste binnedring deur middel van mites, drome, kuns, rituele en simptome. Dit kan verskyn as figure soos die moeder, die held, die kind, die wyse ou man of as gebeurtenisse soos geboorte, wedergeboorte, dood, transformasie, inisiasie of as magte soos vuur, water, balans, beskerming, eenheid en lewe. Argetipiese simbole kan 
saamsmelt, of uit mekaar ontwikkel, of dieselfde simbool kan verskillende betekenisse hê. Om dié simbole te verstaan, is 'n vergelykende studie van drome, mites, sprokies en kunswerke nodig.

E Neumann noem verskillende eienskappe van argetipes. Dit is onsigbaar, maar altyd teenwoordig en beïnvloed die mens se gedrag onbewustelik. Dit is dinamies en manifesteer in energieprosesse, emosies en buie. Dit manifesteer deur middel van beelde wat deur die bewussyn waargeneem word. Verskillende argetipes en verskillende aspekte van 'n argetipe kan deur verskillende beelde voorgestel word. Die argetipes kan ook met mekaar oorvleuel. Neumann (1955: 9) stel dit soos volg:

Although all these many forms are ultimately 'variations of a ground theme', their diversity is so great, the contradictory elements united in them so multivarious, that in addition to speaking of the 'eternal presence' of the archetype, we must also speak of its symbolic polyvalence.

Neumann (1955: 6) maak 'n duidelike onderskeid tussen die argetipe an sich en die simbole wat die argetipe verteenwoordig:

The archetype an sich is an irrepresentable factor, a disposition, which starts functioning at a given moment in the development of the human mind and arranges the material of consciousness into definite patterns.

Jung lê 'n baie noue verband tussen argetipes en instinkte. Vir hom is die argetipes onbewuste beelde van die instinkte van die mens (Jung 1959: 43). Daar is ook net soveel argetipes as wat daar tipiese situasies in die lewe is. Wanneer 'n situasie ontstaan wat met 'n sekere argetipe ooreenstem, word daardie argetipe geaktiveer sodat dit ' $n$ oorweldigende, dwingende uitwerking op die persoonlikheid het (Jung 1959: 47).

\subsection{Bewussyn en ego}

Die ego is vir Jung die middelpunt van die bewussyn. Dit is die draer van die identiteitsgevoel, selfbewussyn en persoonlike kontinuiteit in ruimte en tyd. Dit is ook die setel van die wil, geheue en aandag.

Die bewussyn het vir Jung betrekking op 'n verhouding, naamlik op die verhouding tussen die psigiese inhoude en die ego. Jung (1971: 421) definieer dit soos volg: 
By consciousness I understood the relation of psychic contents to the ego, in so far as this relation is perceived as such by the ego. Relations to the ego that are not perceived as such are unconscious. Consciousness is the function or activity which maintains the relation of psychic contents to the ego.

Die bewussyn ontwikkel uit die oorspronlike sisteem van die kollektiewe onbewuste as deel van die evolusieproses van die mens. Dié filogenetiese ontwikkeling van die bewussyn veroorsaak dat die primitiewe mens van die ontwikkelde, beskaafde mens verskil. Die primitiewe mens se funksies van denke en wil is nog nie gedifferensieer nie.

Hierdie funksies is nog voorbewus omdat die primitiewe mens nie doelbewus dink nie, maar beleef dat gedagtes in sy bewussyn verskyn (Jung 1969: 153). Sy lewe word meer deur onbewuste as bewuste prosesse beheer, meer deur argetipiese beelde as intellektuele konsepte en meer deur instinkte as deur wilsbesluite van die ego. Sy psige is nie behoorlik geïntegreer nie en kan maklik as gevolg van onbeheerde emosies disintegreer.

Die primitiewe mens leef in groter eenheid met die natuur waarop hy die onbewuste inhoude projekteer. Sy bewussyn word voortdurend bedreig deur die onbewuste wat dit wil verswelg.

Die moderne ontwikkelde mens het die antropomorfistiese projeksies op die natuur deur sy ontwikkeling van objektiewe waarneming en wetenskaplike insig onttrek. Sy mistiese identiteit met die natuur is gevolglik deurbreek en hy beleef ' $n$ geïsoleerdheid in ' $n$ ontmenslike kosmos (Jung 1977: 255). Die emosionele energie wat aan die kommunikasie met die natuur verbonde was, het in die onbewuste gesink. Hierdie verlies aan kommunikasie word gekompenseer deur simbole in drome. Hierdie simbole verteenwoordig die mens se oorspronklike natuur, instinkte en eiesoortige denke (Jung 1977: 255).

\subsection{Die persoonlike onbewuste en komplekse}

Die persoonlike onbewuste bevat inhoude wat bewus was, maar vergeet, verdring of geïgnoreer is, of wat te vaag of indirek was om 'n indruk op die bewuste te maak. Dit word gevul deur persoonlike ervarings (Engler 1985: 84) en dit bevat ook aspekte van die persoonlikheid wat nie op bewuste vlak uitgeleef word nie. Inhoude wat reeds bewus was, kan spontaan te voorskyn kom of kan deur die bewussyn bereik word deur middel van gewone geheueprosesse, assosiasies en hipnose. 
Komplekse word gevorm wanneer die persoonlike onbewuste individuele ervarings in groepe versamel. Engler (1985: 85) definieer 'n kompleks soos volg: 'A complex is an organized group of thoughts, feelings and memories about a particular concept.'

Grobler (1978: 35) gee 'n meer uitgebreide definisie van 'n kompleks soos volg: "n Kompleks bestaan uit 'n kern met 'n aantal assosiasies wat daaraan verbonde raak. Die kern is ' $n$ argetipe, die assosiasies berus op persoonlike ervaring van ooreenstemmende begrip, lewensituasie of gebeurtenis.'

Komplekse kan as die basiese struktuur van die psige beskou word. Party komplekse is onaktief en het 'n skaars merkbare uitwerking op die persoonlikheid. Ander komplekse is aktief en kan selfs die bewussyn oorweldig. Jung benadruk die outonomiteit van die komplekse wat soos verskillende persoonlikhede kan optree of in psigoses as stemme en gesigte waargeneem word.

\subsection{Die persona en die skaduwee}

Die persona van die mens verwys na die sosiale rol wat die mens op aandrang van die gemeenskap moet vervul. Anders gestel, die persona is die masker wat die mens dra in 'n poging om aan die eise van die gemeenskap te voldoen. Dit verteenwoordig 'n kompromie tussen die mens se ware self en die eise van die omgewing (Engler 1985: 87).

Die skaduwee is die teenpool van die persona en verteenwoordig die kwaad in die mens. 'It could be described as the devil within' (Engler 1985: 88). Die skaduwee is gesetel in die onbewuste van die mens. Hoe meer ' $n$ mens bewustelik probeer om slegs goed te wees en reg te lewe en ontken dat hy ook ' $n$ dierlike, instinktiewe, amorele sy het, hoe sterker word hierdie eienskappe in die onbewuste. Hoewel die ego die hele onbewuste as skaduwee kan ervaar, verwys dit gewoonlik na die onaanvaarbare, ontkende eienskappe in die persoonlike onbewuste. 'The educated man tries to repress the inferior man in himself, not realizing that by doing so he forces the latter into revolt' (Jung 1969: 79).

Die verdringde eienskappe is meesal teenstrydig met morele en etiese opvattings. Wanneer dit as personifikasies in drome en verhale voorkom of na buite geprojekteer word, neem dit die vorm van bose, bedreigende figure aan. In mites en sprokies is daar voortdurend 'n stryd tussen goed en kwaad wat gewoonlik die stryd van die ego (held) teen die oormag van die onbewuste (draak of monster) weerspieël. In 
drome is die skaduwee dikwels ' $n$ bedreigende figuur van dieselfde geslag en van 'n ander ras of 'n gevaarlike dier.

As projeksie verskyn die skaduwee in grade vanaf ' $n$ kritiese of suspisieuse houding tot by Martin Luther se duiwel wat hy met 'n inkpot gegooi het.

\subsection{Die self en die individualisasieproses}

Die self is ' $n$ term wat Jung gebruik om die totaliteit van die psige, die bewussyn sowel as die onbewuste, mee te beskrywe. As argetipe beteken die self heelheid, volledigheid, volmaaktheid. Hierdie heelheid word bereik wanneer die bewussyn en die onbewuste versoen word deur middel van ' $n$ dialoog tussen die ego en die onbewuste. Dit word die transendente funksie genoem en vorm deel van die proses van individualisasie wat gerig is op die bereiking van die self.

\section{DIE SKEPPINGSMITES AS SIMBOLE VAN DIE PSIGIESE PROSESSE}

\section{1 'n Bepalende stelling}

Die stelling wat uit die Jungiaanse perspektief van die dieptesielkunde hier geld, is die volgende: Skeppingsmites verteenwoordig onbewuste en voorbewuste psigiese prosesse wat die oorsprong van die mens se bewuswording van die wêreld beskryf (Von Franz 1975: 8).

Dit beteken dat die skeppingsmites nie die oorsprong van die kosmos beskryf nie. Dit verwys na psigiese prosesse wat die groei van die bewussyn van die mens uit die onbewuste begelei.

\subsection{Die ontwaking van die bewussyn}

In die heel vroeë stadium van die menslike ontwikkeling het daar geen onderskeid tussen die onbewuste psige van die mens en die objektiewe wêreld bestaan nie. Daar het ' $n$ toestand van volkome gelykheid of ' $n$ argaïese identiteit geheers. Psigiese mutasieprosesse het begin plaasvind wat hierdie argaiese identiteit versteur het en die groei van die bewuste geïnisieer het (Von Franz 1972: 7).

Aanvanklik was daar dus by die mens geen verskil tussen wat innerlik of uiterlik gebeur nie. In die skeppingsmites word dié oorspronk- 
like toestand as ideaal of as 'n volmaakte toestand voorgestel.

Neumann (1954: 12) beskryf dit soos volg: 'It is the time of existence in paradise where the psyche has her preworldly abode, the time before the birth of the ego, the time of unconscious envelopment, of swimming in the ocean of the unborn.'

Die begin van die mens se ontwikkeling uit die oertoestand word as die uroboros-fase beskryf. Die Uroboros is die slang wat sy stert byt en vir ewig lewe. Die sirkel wat gevorm word, verwys na volmaaktheid. Hierdie 'hemelse slang' wat die onbewuste in skeppingsmites simboliseer, se omvattende funksie word soos volg deur Neumann (1954: 10) beskrywe: 'It slays, weds, and impregnates itself. It is man and woman, begetting and conceiving, devouring and giving birth, active and passive, above and below, at once.'

Hierdie fase word gevolg deur die matriargale fase wat deur die moedergodin oorheers word. Verdere ontwikkeling deur die ego word deur die heldemite uitgebeeld waar die held die moederlike draak (of onbewuste) moet oorwin, probleme moet oorkom, die meisie (sy anima) bevry of soek na 'n skat (die self).

Wanneer die argaiese identiteit versteur word, maar die differensiasie van die subjektiewe en die objektiewe nog nie voltrek is nie, vind projeksie van die argetipes plaas. 'Projection results from the archaic identity of subject and object, but is properly so called only when the need to dissolve the identity with the object has already risen' (Von Franz 1972: 6).

Met die ontwikkeling van die bewussyn begin diskriminasie plaasvind en teenoorgesteldes soos goed en kwaad (persona en skaduwee) kom te voorskyn. Daar vind 'n fragmentering van die argetipe plaas en daardeur kan die ontbinding van die projeksie en assimilasie van gedeeltes begin. Die moederargetipe ondergaan byvoorbeeld só ' $n$ verdeling in die goeie moeder en 'n vernietigende mag wat manlik van aard is. Dit dui op weerstand teen die mag van die onbewuste, wat egter nog te sterk is, en lei tot kastrasie of vernietiging.

In die voorbewuste is daar twee magte: Die een is 'n neiging to verdeling, bewuswording, die ontwikkeling van die individu; die ander is die neiging van die onbewuste om heel te bly, in 'n onbewuste kollektiewe toestand. Elkeen het positiewe en negatiewe kenmerke. Bewussyn bring eensaamheid, konflik, skuld en uiteindelik die gevaar van kunsmatigheid en steriliteit as gevolg van verbreking van kontak met die natuur. Aan die ander kant kan daar geen ontwikkeling sonder bewussyn en ' $n$ integrerende ego wees nie. Die nadele is die prys wat 
betaal word vir die uiteindelike doel, naamlik integrasie in 'n groter eenheid op 'n hoër vlak. Die onbewuste word deur die ontwikkelende egobewussyn waargeneem as negatief, verswelgend en vernietigend. Tog bevat die onbewuste 'n natuurlike, instinktiewe wysheid wat vir die primitiewe mens, wat dit nog nie met 'n diskriminerende bewussyn kan vervang nie, absoluut noodsaaklik is. Hy kan nog nie individueel optree nie en is op die groep en die kollektiewe onbewuste aangewese (Von Franz 1972: 210-213).

Die onbewuste het 'n remmende invloed op die ontwikkeling van die bewussyn. Dit word in skeppingsmites gesimboliseer deur wesens wat geskep word en weer verdwyn.

In die skeppingsmites verteenwoordig reuse geweldige emosies, ondiere is verwarde emosies en Germaanse dwergies verwys na skielike ingewings. Konflikterende argetipes word gesimboliseer deur die stryd tussen gode, of tussen gode en reuse. Die slang het ' $n$ veelheid van betekenisse, waaronder onsterflikheid en donkerte, geassosieer met die gode van die onderwêreld, met wysheid en soms met die kwaad. Die slang as Uroboros hou verband met die chaos in die begin en is simbool van die bewussyn wat begin om uit die onbewuste te ontwikkel.

\section{SLOTOPMERKINGS}

Dikwels word skeppingsmites as verhale beskou wat 'n kosmogonie verteenwoordig. Jung het egter vanweë sy studie van die psigologie, mitologie, alchemie, argeologie en volkekunde 'n psigologiese model ontwerp wat ' $n$ ander dimensie van skeppingsmites blootlê. Skeppingsmites is simbole van psigiese prosesse van die menslike onbewuste. Sy aanname wat tot hierdie tese gelei het, is dat alle produkte van die psige soos drome, simptome, kunswerke, argitektuur, godsdiens, mites, legendes en sprokies lig werp op die aard en funksionering van die psige.

In sy model vind hy aansluiting by Sigmund Freud. Hy delf egter dieper as die persoonlike onbewuste (Freud) en beskryf die kollektiewe onbewuste en die groei van die ego uit hierdie onbewuste. Alhoewel sy model kontroverseel van aard is, is daar vandag toenemende belangstelling in Jung se werk by psigoloë, filosowe, teoloë, volkekundiges, letterkundiges en kunstenaars.

Sy model lewer ' $n$ bydrae om iets te verstaan van die groot geheimenis van menswees. 


\section{Literatuurverwysings}

BRAMMER, LM \& SHOSTROM, EL 1982. Therapeutic psychology. New Jersey: Prentice Hall.

ENGLER, B 1985. Personality theories. Boston: Mifflin.

GROBLER, E 1978. 'n Dieptesielkundige ontleding van 'n aantal Bantoeverhale. MAverhandeling, Universiteit van Pretoria.

JUNG, CG 1959. Aion: Researches into the phenomenology of the self. Collective Works, Vol 9, Part II. London: Routledge and Kegan Paul.

JUNG, CG 1969. The archetypes and the collective unconscious. Collective Works, Vol 9, Part I. London: Routledge and Kegan Paul.

JUNG, CG 1971. Psychological types. Collective Works, Vol 6. Princeton: Princeton University Press.

JUNG, CG 1977. Symbolic Life. Collective Works, Vol 18. London: Routledge and Kegan Paul.

NEUMANN, E 1954. The origins and history of consciousness. London: Routledge and Kegan Paul.

NEUMANN, E 1955. The great mother: An analysis of the archetype. London: Routledge and Kegan Paul.

VON FRANZ, M-L 1972. Patterns of creativity mirrored in creation myths. Zurich: Spring Publications. 
